\title{
Corruption In Nepal: An Anthropological Inquiry
}

\author{
Madhusudan Sharma Subedi*
}

\begin{abstract}
Both bribe receiver and bribe offerer are enemies of the nation. Prithivi Narayan Shah, the Founder of the Modern Nepal.
\end{abstract}

\section{Introduction}

For at least a decade and more obtrusively in recent years, the problem of corruption has been at the center of the political agenda in Nepal. It is recognized as one of the chief causes of Nepal's underdevelopment. It is very widespread, has different manifestations, and is practiced at all levels of society. The Nepali bureaucracy, politician, and the business sector are most seriously affected by, and inextricably involved in corruption. This is really a great challenge to the campaign of modern Nepal (Upadhaya 2003). The businesspersons, the politicians, government officials, so called academicians and even consumers are responsible for this. The intention of this paper is to classify the various forms of corruption in order to operationalize the concept for analytical and practical proposes. First, I will outline the different forms of corruption prevailing in Nepal. Secondly, I will propose some issues to fight against corruption, a broader agenda of democratization.

\section{Understanding Corruption}

Corruption is a complex and multifaceted phenomena with multiple causes and effects, as it takes on various forms and functions in different contexts. The phenomenon of corruption ranges from single act of activity contradicted by law to way of life of an individuals or groups. The definition of corruption ranges from the broad terms of 'misuse of power and authority' to 'moral decay' (Amundsen; Sissener and Soreide 2000). Corruption is conventionally understood, and referred to, as private wealth-seeking behavior of someone who represents the state and public authority. It is the misuse of public goods by public officials, for private gains. In simple terms corruption may be described as "an act of bribery" or "the use of public power for private profits in a way that constitutes a breach of law or a deviation from the norms of society (Amundsen 2000)". It is a misuse of authority as a result of consideration of personal gain, which is not necessarily monetary. This private gain is achieved by ignoring prohibitions against certain acts, by exercising legitimate discretion to act, or by fulfilling obligations to act. This is the abuse or misuse of public offices, professional rights and duties for personal gains. The genesis of corruption is found within the international, the national institutional and national societal levels. At the international level, the globalization of markets, finances and numerous other transactions between various players in the global game and the "host" government and its representatives take part in this game. Multinationals are, for instance, buying concessions, preferences and monopolies; kickbacks are offered on tenders, loans and contracts, and development projects are sometimes eased through by including travels, computers, and other fringe benefits for officials (Amundsen 2000). There is no question that corruption is, before anything, a type of crime (Lederman et al. 2001). However, the discourse of corruption varies a great deal from one country to another with particular historical trajectories and the specific grammars of public culture (Gupta 1995).

\footnotetext{
${ }^{*}$ Mr Subedi is a Lecturer on contract at the Central Department of Sociology/ Anthropology, Kirtipur.
} 
At the national institutional level, corruption takes place between the government (the executive) and the administrative and bureaucratic institutions (the civil service, judiciary, legislature, and local authorities). The relationship can be corrupted because of overlapping and conflicting authority, political power struggles over access to scarce resources, and personal relationship of dependence and loyalty. Other contributing factors are, a weak separation between civil service and partisan politics, a weak professionalization of the bureaucracy, a lack of accountability and transparency, and deficient political control and auditing. The more discretion officials have through abundant, complex and non-transparent regulations, the more corruption becomes likely (Amundsen 2000; Bista 1991; Pyakuryal 2000).

On the national societal level, the corrupt relationship happens between the state and various nonstate actors - corrupt state officials and the supplier of the bribes. It can be the general public, any nongovernmental and nonpublic individual, corporate and organizational, domestic and external.

Corruption, however, also exists within and between private businesses and within nongovernmental organizations, without any state agency or state official being involved. There is a corruption in terms of bribing, swindling and mafia methods in business, and there are treacherous individuals and disloyal employees in many private firms, organizations and associations. Besides, corruption also exists as a moral and cultural problem in society, among individuals in their personal dealings.

\section{Forms of Corruption}

The main forms of corruption are bribery, embezzlement, fraud, and extortion. Even when these concepts are partly overlapping and at times interchangeable with other concepts, some of the basic characteristics of corruption can be identified through these concepts (Amundsen 2000).

Bribery: Bribery is the payment that is given or taken in a corrupt relationship. A bribe is a fixed sum, a certain percentage of a contact, or any other favors in money or kind, usually paid to a state official who can make contracts on behalf of the state or otherwise distribute benefits to companies or individuals, businessmen and clients.

There are many equivalent terms to bribery, like kickbacks, gratuities, baksheesh, sweeteners, pay-off, speed and grease money, (Amundsen 2000) which are all notions of corruption as perceived from below, from public. These are payments needed or demanded to make things passed swifter, smoother or more favorably through the state bureaucracy. By "greasing palms" corporations and businesses interests can buy, for instance, political favors and escape the full burden of taxation and environmental regulation, or buy protected market and monopolies, import/export licenses etc. Bribery can also be a form of "informal" taxation, when public officials charge additional amount under-the-table payments (called ghush in Nepali) or expected "gifts" from clients.

Embezzlement: It is the theft of public resources by public officials, which is another form of misappropriation of public funds. Embezzlement happens when a state official steals goods and resources from the public institution in which he/she is employed, and from resources he is supposed to administer on behalf of the state and the public. However, corrupt employees in private firms can also embezzle money and other resources from their employers. Some people think that embezzlement is not considered as corruption from a strict legal point of view. In general terms, corruption is a transaction between two individuals; state agent and other civilian, when the state agent goes beyond the limit of the law and regulation in order to secure 
himself/herself a personal benefit in the form of a bribe. Embezzlement is regarded as theft because it does not involve the "civilian" side directly. The general public is deprived when public funds are embezzled, but individual property is not stolen, and it is argued that the individual citizen will have no legal right to present themselves as forfeited. This is a very dangerous argument. There has to be a political will and legal capacity as well as public sanction to control it. In Nepal, embezzlement is one of the most important modes of economic accumulation. In fact political leaders and higher administrative bureaucrats are earning money by this method. Otherwise, how is it possible to earn multi million rupees within a few years of bureaucratic post or being a political authority? It is a fundamental part of the resource extractive capacity of the ruling elite, and it should be taken more seriously than extraction through bribes.

Another form of embezzlement is - some power holders systematically use their political office to enter into, secure and expand their private business interests. In Nepal, the political elites have link with businessperson, decision makers and control media personnel, development workers and human rights activists through their contact. They hold a major share in private schools and colleges, and nursing homes, pharmaceutical companies, transport and media and many more ventures.

Fraud: This is a serious crime that involves some kind of dishonesty, swindling or cheating. When the ministers, bureaucrats and academicians take their share for closing their eyes when they have an active role in it. This is also known as phohari khel or phohari rajniti, 'dirty politics'. Dirty politics include, giving unnecessary loans that will never be paid back, provide contracts without competition, issuing license to manufacture poor qualities of medicines to pharmaceutical companies, approving bills without proper supervision, select less qualified and unskilled persons, transferring qualified bureaucrats to other places if he/she is not favoring political authority. This dirty politics is tied to the interest of national and international agencies and authorities and the dominant feudal culture. In Nepal, dirty politics is playing a major role in the selecting, nominating and promoting of less qualified, politically corrupt people in vital posts.

Extortion: It is money and other resources extracted by the use of coercion, violence or threat to use force. By creating an atmosphere of insecurity where individual citizens, private businesses and public officials are harassed and intimidated. Only those who pay the protection money will be exempted from further harassment. With more or less concealed threats, rulers can extract resources from private source businesses. These businesses rarely take the chance of refusing state or ruling party officials. The present political conflict has played very important role for promoting such extortion in Nepal.

Favoritism : It is a mechanism of power abuse implying "privatization" and a highly biased distribution of state resources, no matter how these resources have been accumulated in the first place. It is the tendency to favor family, friends, relatives, clan, caste, ethnic group, gender, race, place of origin, members from the same party, and anybody closed and trusted. In political sphere, it is the liking of state officials and politicians who have access to state resources and the power to decide upon the distribution of these, to give preferential treatment to certain people. It is a basic political mechanism in many autocratic and semi-democratic countries. In Nepal, the Prime Minister has the constitutional rights to appoint all high-ranking positions, legal or customary rights that extend exceedingly the possibilities for favoritism. It easily adds up to several hundred positions within the ministries, diplomatic organization and other line agencies.

Nepotism: It is a special form of favoritism, in which an office holder (ruler) prefers his proper kinfolk and family members (wife, son, daughter, brother, sister, nephew, cousins, in-laws etc.). Many political leaders have tried to secure their power position by nominating their family 
members to political, economic, various public councils and committees and security positions in the state apparatus. Through such mechanisms, many politicians and bureaucrats have been able to move their family members from public position into private business, to transfer public power to private wealth. Favoritism is not only a legal problem, but also a problem of flawed qualifications, lacking skills and inefficiency (Amundsen 2000). Further where public position is strongly correlated to possibilities of corrupt and extractive practices, favoritism can secure substantial prerogatives and profit for certain families, clans or some social subgroups.

\section{Corruption in Nepal: A Quick}

The issue of corruption is an old one that has reentered the current political, economic debate from the new interest in the role of the state in the developing world, and from the assumption that the state is an indispensable instrument for the economic development, redistribution and economic welfare.

After the restoration of democracy in Nepal, we have seen a significant institutional development in the political sphere of the country. Many small political parties have been emerged while many new faces have been seen in the major political parties. However, key political affairs in the country is still-like in Panchayat days- being run by the few elites that control, influence and manipulate the construction of political and economic mainstream of modern Nepal (Subedi 2001). These elites maintain the formal as well as informal networks within their groups. These practices are too deeply embedded in the lives and social interaction of society and it is doubtful they will change in the near future (Levitt 1999). On the one hand, we are reading the news and views of corruption in everyday newspapers and seminars and on the other hand, corrupt people are enjoying political power, property and honor. Of these, the major forms of corruptions that are being practiced in Nepal are:

Bribe: As stated earlier, it is the payment that is given or taken in a corrupt relationship (money offered in cash or kind or gift as inducement to procure illegal or dishonest action in favor of the giver), nepotism (undue favor from holder of patronage to relatives), misappropriation (using other's money for one's own use), patronage (wrong support / encouragement given by patron and thus misusing the position), and favoritism (unduly preferring one to other). In bureaucracy, for example, a foreign consultant may help one or two of the counterpart's children get admitted to one of the universities abroad. Nepali bureaucrats culturally feel so much obligated with this kind of help by the consultant that the counterpart may then do any unethical thing for the consultant's benefit (Pyakuryal 2000). Similarly, in education senior professors help junior and newly recruited individuals based on their own political affiliation rather than his/her teaching ability, publications and academic background. The seniors, at the same time want to get undue advantages from their political lobbing and affiliations.

The Nepali business community often claims that it is forced to pay bribes because of business unfriendly nature of many aspects of government policy, legislation and procedures. They say that it is often easier to hand over a bribe than to waste time and forego profits trying to legally overcome the hindrances put in their way by government officials. Political elites are loosing confidence of being honest. The government employs in all public concerns at all levels are demanding huge bribes even for small considerations. Explaining the situation of business related corruption one businessman in Kathmandu said:

Government customers and tax officials demanding bribe from businesses to issue licenses and tax clearance certificate, and to allow goods to be imported. Politician demanding donations from businesses and businesses demanding favors in return. 
Businesses cheating consumers and adulturing goods and creating false scarcities. The range of malpractice prevalent in government tenders.

This situation has severely damaged the competitive strengths of Nepali business. It has also, in many cases, increased the cost and undermined the quality of goods and services available to consumers, and deprived the government of much needed revenue.

Today, both at the central and the local levels, the number of ministers and political leaders with an honest image can be counted on fingers. The licensing system of the government, the control regulations, and the expansion of the public sectors spread corruption in all walks of life. At present, Nepal is viewed as one of the most corrupt country in the world according donor organizations and financial journalists.

Chakari: Chakari is an essential concept which means to wait upon, to serve, to appease, and to seek favor from politically or administratively well off people. According to Bista (1991), “ Chakari was officially introduced into secular life during the Rana period, mainly as a form of control designed to keep potential rivals or opponents away from belligerent activities. These potential rivals were required to spend time generally in attendance at the Rana palaces, where at certain hours the Rana would be able to observe them physically and know that they were not somewhere else fomenting troubles. This was done very formally, usually in the afternoon, and the hours set aside for this purpose were known as the chakari hours (Bista 1991:90)." Anyone who did not appear for chakari was immediately suspected as at least unreliable and therefore unworthy of retaining a job. Consequently, government employees had to perform chakari to ensure job security and in order to be eligible for promotion. Actual job performance was not of paramount importance, although sometimes it could be an added criterion for promotion. Those seeking improvement in life via this practice are called chakariwal, people practicing chakari. With the end of Rana rule, chakari was formally abolished, but then it had firmly installed itself as an integral feature of Nepali social organization. Today, chakari remains an integral part of social life and it is evident at all levels of government. Chakari is performed at the house of the person or party office whose favors are being cultivated, where there is some assurance of actually seeing him/her. Besides presenting oneself and offering greetings, other forms of chakari include offering gifts, either material gifts or gifts in services and favors. For the important, there will be a number of chakariwal in attendance everyday. Most grievance procedures are affected through chakari channels (Bista 1991:91-94).

The gift donor in chakari has certain rights. There is an obligation on the part of the recipient to respond to the chakariwal when the chakariwal so determines.

In many cases chakari takes the forms of a bribe or other form of corruption. For example, Caplan (1971:274) writes-

"the practice of chakari is considered a necessary and appropriate method of getting employment. It is recognized as demeaning to the supplicant, but no man loses esteem in the eyes of other residents if he demonstrates weakness before and dependence upon the administration. To do this is merely to accept reality."

Decisions are made, appointments determined because of pressing obligations formed through chakari and not as a result of an objective determination of what is best at the point. The whole chakari plays a negative role in the administrative and political life.

Afno Manche: This is the term used to designate one's inner circle of associates- it means one's own people and refers to those who can be approached whenever need arises (Bista 1991:98). Academic qualification, training background, working discipline, work experiences, integrity of 
character and other such attributes are not as important or helpful as the sense of belonging to a particular circle. A member of one's own circle is naturally preferred, even without particular capacity to perform in some organizational role. The most important asset for anyone is not what you know, but who you know (Bista 1991:98). The 'natabad', helping kin, and 'crypabad' helping others are very common in Nepal. Natabad, crypabad, phariyabad, hanumanbad, is translated to favoritism, favoring afno manche. It is a circle of mutually supporting associates, which personal ties cut across and through the supposed impersonalities of bureaucracy. Adams (1998:39) writes, for example;

"If one needed any sort of privilege from a ministry, one would consider if one had afno manche in that ministry on whom one could rely for processing one's request. If no family connection existed, one might consider chakari to create a basis for obtaining favors from a status superior. ... Thus creating afno manche relationship through marriage, politics, and a multitude of social events (worship events, parties, gambling, social clubs, sports, hobbies, etc.), a primary strategy for economic, political and social mobility."

Bista (1991) says that almost each activity is influenced by Afno manche: the length of the time to cash a cheque, the treatment one receives in hospital, one's child is success at school; all are influenced by afno manche connection. Previously, the concept of afno manche was applied to nearest kin group (Bista 1991) or a person's connection with key decision makers (Weiner 1989).

After the 1990s movement and introduction of multi-party system, in my opinion, its paradigm has been shifted strongly to political affiliation. Things are not running according to the mandate of the sovereign people and the very spirit of the constitution of an independent and sovereign state. Most of the leaders who are in power have little time or interest to the public. They are very much concerned on political game, individual and party benefit issues and misuse of power. The media are very weak and extremely biased because of their affiliation to one or another political party.

Many good reports might have prepared and submitted to the concerned authorities and many people might have been awarded with many honorary awards and medals. But the people of Nepal if remain in the same stage, might be even worse condition if we compare the status of Nepal with the outside world in the 1950s. It means that development efforts made in the past has raised serious questions in managing national affairs for the benefit of the Nepalese people.

\section{Key Holders of Corruption in Nepal}

After the restoration of multiparty system in Nepal, we have seen a significant institutional development in the political sphere of the country. Many small political parties have emerged while many new faces have been seen in the major political parties. However, the key political affairs of the country is still - like in Panchayat days - being run by the few elite that control, influence and manipulate the construction of political and economic mainstream of modern Nepal (Subedi 2001). These elites maintain the informal as well as formal networks within their groups. We have seen this over the last 14 years when there has been a frequent turnover of the government. In almost 16 different governments that have been seen over the last 14 years, we have seen, in many cases, the same set of people representing different portfolio at various points of time. Innovation, creativity, and discoveries are only possible with the new faces, new minds and new ideas. Will any person, with creative and fair-mind, have a place within the narrow lane of network in which the current political framework is working? Existing political and social situations show that the answers are negative. If things remain same, the economic disparity, political instability, educational inequality, and social security troubles will continue to persist in 
Nepal, and this situation will help those people who are involved in corruption. As, a prominent sociologist with considerable development experience sees "corruption and greed as two of the most important factors that have hindered the Nepali society from moving ahead (Pyakuryal 2000:21).” He further writes:

During the period of hung parliament, the lawmakers were sold and bought for millions of rupees by political parties for defecting from or supporting the parties. These political parties had to collect this money from business houses or even smugglers. What would we then expect from such leaders or the parties that had no choice than to surrender to the investors? These lawmakers made business by passing a bill in the parliament to get all tax exemption for the parliamentarians on imported vehicles. Businessmen and smugglers imported costly vehicles on the MP's quota, and as commissions, those MPs either took cash or cheaper vehicles from their investors. Some other rented their vehicles to earn money. Several of the MPs who had their constituencies on the high hills where there were no motorable roads also imported vehicle for accumulating money. Those MPs were not even ashamed of smuggling men and women to foreign countries by misusing their diplomatic (red) passports. They even handed over their diplomatic passports to the smugglers who imported foreign goods and materials with all duty exempted at the airport custom. Thus there was an utter misuse of authority, and those who misused most might have earned most, and they were the ones who succeeded in becoming more powerful. (Pyakuryal 2000:21-22)."

Thus, the lawmakers in Nepal developed the "pajero" culture, which is synonymous to a corrupt parliamentarian. Pyakuryal further writes that some diplomats in Kathmandu, the capital city of Nepal, who in the name of supporting democracy in Nepal, got involved in financing these corrupt politicians and parties. As a result, social status remained only on the money and power, irrespective of its source. People with black money have gained power and emerged as elites of the nation. The situation also gave a positive chance for the emergence of wing of contractors and sub-contractors within the institutionalized pattern of corruption in Nepal (Upadhaya 2003).

Corruption among public servants has always existed in one form or the other although its shape, dimension, textures and shades have been changing from time to time and place to place. At one time, bribe was paid for getting wrong things done but now the bribe is paid for getting right things done at the right time. Honest politicians are a rare breed today. Corrupt politicians not only go scot-free, unharmed and unpunished but also they manage to strut on political stage as honorable leaders. In this land, those who plunder the country masquerade as honorable citizen with all the paraphernalia merely because they happen to be bigwigs in politics or are close to centers of power. In the last one-decade or so, several scandals and financial irregularities, including paying of massive commissions, pay-off and kickbacks, have been reported in our country. Mostly, it is the Prime Ministers, Ministers, and leaders holding important political positions, bureaucrats and big businessmen who are reported to be involved in these scams. But nothing tangible has been done in uncovering, tracing, apprehending, prosecuting and punishing the culprits on the plea of inadequate evidence. While most people would say they know corruption while they see it, debate continues over the best way to define the concept for analysis. Which acts have been called 'corrupt' in politics and public service? More recently, most definition(s) have focused on the classification of behaviors employing various standards, such as law, public opinion, or the ideas of public interest, to identify abuse of office for the private benefit. The following patterns of behavior among politicians and public servants can be described as corrupt within the provision of law: acceptance of gratification as reward for work in an official capacity, obtaining any object or pecuniary advantage illegally, fraudulent misappropriation of public property, being in possession of financial resources or property disproportionate to one's known sources of income, misuse or abuse of official position, 
borrowing money for purchasing a costly article from a person with whom one has official dealings with a known understanding that the borrowed money will not be returned, accepting gifts by persons of position from persons with whom they have positional relations, disregard of neglect of rules purposely to help the citizen in dues/tax/duty due to be paid to government, refusal to do a duty on some plea which may benefit the other party and others.

There are different ministries in the government, which are regarded as gold mines for making money. Defense Ministry, Home Ministry, Ministry of Finance, for example, spend a huge amount of total budget every year and it is said that commission between 15 to 50 percent are not uncommon on purchasing of weapons, spare parts, emergency expenditure, payments of bills, passing bills, issuing cheques, approving supplies, settlements of disputes and so forth. People say that out of total cost sanctioned for the project, about 30 percent is invested in the work, 30 percent on contractor's profit, and 40 percent goes into various ministers' and officers' pockets. The power enjoyed by ministers and police are so wide that they can accuse, arrest, and harass even an honest person. It is said that the failure to pay commission results in delay in getting the bill passed and receiving the cheque.

The causes of corruption are sought in wholly different directions, depending on the ideological stance and preferences of the seeker. The neo-liberal school considers corruption to be one of the effects of the black market caused by excessive state interventionism. The more the state intervenes, the more it legislates, and the more it develops interfering bureaucracies, the greater the risk of parallel procedures and market spawning unlawful conduct. On the other hand, those who are not convinced of the state's intrinsic perversity or market's unquestionable merits stress another aspect: the erosion of the public ethics, lack of political culture to politicians, domination of dirty politics to the state bureaucrats, the loss of state's legitimate status as the incarnation of the general interest, and the dilution of communal values through the pursuit of profit and the defense of selfish private interests. However, these causes are not mutually exclusive.

\section{Reconsidering Methods and Approaches}

Since corruption is a sensitive topic, the methodological tools appropriate for analyzing the habitually concealed and under-communicated, usually illegal practices like corruption, the conventional tools and techniques are not sufficient. The current scholarly approaches to corruption and its effects resolutely avoid the moral questions and concentrate entirely on technical issues (Bukovansky 2002). Thus, it is very urgent to a broader understanding of the phenomena. Similarly, conventional methods of data collection (questionnaires or interview method, for example) are not applicable to study types, forms and degree of corruption. Since corruption does not take place where the researcher is looking for its everyday manifestation might be elsewhere. This everyday dimension is often overlooked by other social sciences and has as a result been lacking in literature on corruption. The indirect field methods are particularly apt in getting information properly. I emphasize "covert participant observation" as a useful method to study about sensitive topics like corruption. Informal conversation and people's everyday discourses are rich in anecdotes, confession and accusations, through which both substantiations and assessments on corrupt practices can be obtained. We can also study more direct observable activities, like Land Taxation Office, Tax Office, Company Registrar's Office, International Borders, Educational Institutions, and even Hospitals, although at high costs and with serious ethical dilemmas (Sissener 2001) Focus group discussions become fruitful in some situations. Thus, different approaches and methods should be combined to substantiate and verify the findings. We know much more about control of low ranking participants than of high ranking ones, and clearly the control of higher rank is at least as important (Etzioni 1995).

\section{Role of Civil Society and Issues of Good Governance}


The present era is marked by the fact that corruption has become widespread, that it affects more and more spheres of activity, and that it reflects a negative trend compared with the progress made in stamping it out, particularly in democracies. Many businesspersons, government officials and consumers are unaware of the serious impact that corruption has on Nepali economy and society.

The sensitivity of public opinion, towards corruption varies considerably from one country and from one culture to another. Comparable variations are to be found in political systems between public opinion at large and social elite. Whereas latter usually tend to minimize the scale of corruption (often after having ignored or denied it), public opinion has had a marked propensity in recent years to exaggerate its extent. Opinion polls show that the vast majority of the people interviewed are convinced that "more than ninety percent politicians are corrupt". Clearly, and whatever the real degree of corruption, nothing can be adduced as serious evidence for such a claim.

Those disagreements also occur in attempts to define corruption. What is corruption? Is it only the misdemeanor identified as such by the criminal laws specific to political system, or is there a need to give a definition that is less precise but based on more realistic observation of the phenomena. In other words, should we opt for a strictly legal definition, or should we take a more sociological approach?

The legal definition offers the advantage of safety and certainty, i.e., corruption is what the penal code defines as such, or what professional code of ethics prohibits. By establishing what is allowed and what is prohibited, the law lays down in principle clear limits that should not be overstepped. This principle raises two problems, the first being strictly legal and second ethical.

The strictly legalistic approach presents shortcoming in that it tends to sidestep the ethical principles and that are at the very root of repressive measures. Corruption is not an ordinary offence comparable to a highway code or fraud. It constitutes a violation of duties, of office and a negation of the values that should underlie the democratic, political and administrative systems founded on the rule of law, such as distinction between private and public interests, equality of treatment for citizens, transparency of transactions, and so forth. By laying stresses exclusively on the strictly panel definition of corruption, we may lose sights of justification and purpose of these repressive measures.

Governance is a composite form of the state, the private sector and the civil society. The strength of good governance is that where all actors remain close to and co-operating each other. In such situation, they complement to each other and at the same time keep checking and balancing each other to obtain good results. Transparency is the major requirement of good governance. It means that decision taken and their enforcements are done in a manner that follows rules and regulations. It also means that information is freely available and directly accessible to those who will be affected by such decisions and their enforcement. It also refers to the free availability of information to the general public and clarity about rules, regulations and decisions. It also means that processes, institutions and information are directly accessible to those concerned with them, and enough information is provided to understand and monitor them.

Accountability is also a key requirement of good governance. "It is the duty of public officials to report their actions to the citizens and the right of the citizens to take actions against those officials whose conduct is considered unsatisfactory. It is imperative to make public official (decision makers) answerable for government behavior and responsive to the entity from which they derive their authority. The authority or the decision maker is good or bad depending upon 
the level of transparency and accountability in such decision making processes that directly or indirectly affects the public life.

An important activity should be to review business processes, political related legislation and procedures, academic irregularities and to develop the situation for more business friendly, fair election legislation, academic environment and procedures that discourage corruption. The CIAA (Commission to Investigate the Abuse of Authority) has complained that it does not get enough well grounded complaints about political and business related corruption. The other activity would be to collect corruption cases to pass on to the CIAA and to deal with the other ways.

An organized effort and action based on the ground reality is important to influence public policy and decisions that directly or indirectly affects public life. A complaints unit should be set up in favor of fairness, transparency to receive record and take forward complaints by and against existing system of corruption in Nepal. For this, a public action committee should be formed with representative from the business community, lawyers, academicians and local leaders to press the government to crack down on corruption. This organization should put pressure on the government to prevent corruption happening and to prosecute guilty parties. The intention is that, for example, in a case where an HMGN official has demanded a bribe from a businessperson to clear some official procedure, the victimized businessperson would report this case to the Complaints Unit. The unit would then assess the truthfulness of the accusations, and, if convinced, either send a complaint on to the appropriate government authority, such as the CIIA for the government related cases, or deal with it in a alternative way. The complaint unit will work out such as mediation or 'naming and shaming' with the help of media, to deal with corruption cases as a way to bypass the time consuming and expensive process of going to court.

At first it should be an informal group; but later it could develop into a more formal structure or some kind of federated body. The name of corrupt personnel should be published in the media. A website and regular edition of a corporate ethics bulletin plays very important role to sensitize the cases. The website should be used to provide information and expose corrupt officials, businesspersons and academicians. This is also expected to be an important part of the up coming to operate more transparently and to be more law abiding.

\section{Concluding Remarks}

Corruption is an issue in public debates and everyday conversation in many countries. To understand and fight against corruption, the legal definition of corruption is too narrow and only concerns with legal procedure, legal evidences and ignores the people's own assessment of courses of action. If we only give priority to legally sanctioned sphere and ignore socially sanctioned sphere, it is very difficult to fight against corruption in Nepal. This is related to democratization process. Economic and political competition, transparency and accountability, coupled with democratic principles of checks and balance, are the necessary instruments to restrict corruption and power abuse. Civil society should hate, boycott culturally and socially corrupt people for introducing people oriented good government which should be transparent and accountable.

\section{References}

Adams, Vincanne 1998, Doctors for Democracy: Health Professionals in the Nepal Revolution. Cambridge Studies in Medical Anthropology. Cambridge University Press.

Amundsen, Inge 2000, Corruption: Definition and Concepts. Chr. Michelsen Institute Development Studies and Human Rights. 
Amundsen, Inge; Tone Sissener and Tina Soreide 2000, Research on Corruption: A Policy Oriented Survey. Chr. Michelsen Institute (CMI) \& Norwegian Institute of International Affairs, Oslo/Bergen.

Bista, Dor Bahadur 1991, Fatalism and Development: Nepal's Struggle for Modernization. Orient Longman Limited, Calcutta.

Bukovansky, Mlada 2002, Corruption is bad: Normative dimensions of the anti-corruption movement. Department of International Relations, Australian National University, Australia.

Caplan, Lionel 1971, Cash and Kind: Two Media of Bribery in Nepal. MAN. 6:266-278.

Etzioni, Amitai 1995, Modern Social Organization. Foundation of Modern Sociological Series. Eastern Economy Edition, Prentice-Hall of India Private Limited, New Delhi.

Gupta, Akhil 1995, "Blurred boundaries: the discourse of corruption, the culture of politics and the imagined state." American Ethnologists. Vol.22, No.2, Pp 375-402.

Lederman et al. 2001, Accountability and Corruption: Political Institutions Matter. World Bank, Washington.

Levitt, Marta 1999, "A Culturally Appropriate Health Intervention in Conflict with Nepali Management Culture". In Ram Bahadur Chhetri and Om Gurung (eds.) Anthropology and Sociology of Nepal: Cultures, Societies, Ecology and Development. Sociological and Anthropological Society of Nepal (SASON), Kathmandu, Nepal.

Pyakuryal, Kailash Nath 2000, Restoration of Demecracy and People's Empowerment in Nepal. In Occassional Papers in Sociology and Anthropology, Vol. VI (15-25). Central Department of Sociology and Anthropology, Tribhuvan University, Kirtipur, Nepal.

Sissener, Tone Kristin 2001, Anthropological Perspectives on Corruption. Chr. Michelsen Institute Development Studies and Human Rights.

Subedi, Madhusudan Sharma 2001, Medical Anthropology of Nepal. Udaya Books, Kathmandu, Nepal.

Upadhaya, Niranjan Prasad 2003, Corruption: A Psychological Issue. In Occassional Papers in Sociology and Anthropology, Vol. VIII (193-203). Central Department of Sociology and Anthropology, Tribhuvan University, Kirtipur, Nepal

Weiner, Saul, J. 1989, 'Source Force' and the Nepal Medical Profession. Social Science and Medicine. Vol. 29, No. 5, Pp 669-75 